\title{
FITOPLANKTON DAN SIKLUS KARBON GLOBAL
}

Oleh

\author{
Mochamad Ramdhan Firdaus ${ }^{1)}$ dan Lady Ayu Sri Wijayanti ${ }^{2}$
}

\begin{abstract}
PHYTOPLANKTON AND GLOBAL CARBON CYCLE. Scientists around the world believe that phytoplankton, although microscopic, have a large role in the global carbon cycle. Various research results show that the net primary productivity of all phytoplankton in the sea is almost as large as the net primary productivity of all plants on land. Phytoplankton through the process of photosynthesis absorbs 40-50 PgC / year from the atmosphere. Also, phytoplankton is known to be responsible for transporting carbon from the atmosphere to the seafloor through the carbon biological pump mechanism. Phytoplankton from the coccolithophores group is known to play a role in the sequestration of carbon on the seabed through the carbonate pump mechanism. The mechanism is capable of sequestering carbon for thousands of years on the seabed in the form of sedimentary rocks (limestone).
\end{abstract}

Keyword: Phytoplankton, Carbon cycle, Primary productivity, Biological carbon pump, Carbonate pump.

\section{PENDAHULUAN}

Karbon merupakan salah satu unsur yang paling melimpah di alam semesta. Karbon dapat dengan mudah ditemukan di sekitar kita, bahkan di dalam tubuh kita sendiri. Di dalam tubuh manusia, karbon memiliki proporsi sebesar $18,5 \%$ dan menjadi unsur paling banyak kedua setelah oksigen (Campbell et al., 2005). Di alam semesta (universe), karbon menjadi unsur yang paling melimpah keempat setelah hidrogen, helium dan oksigen (Pierson, 1993; Crosswell, 1996).

Karbon memiliki peranan penting dalam kehidupan. Karbon membentuk sebagian besar struktur organik yang ada di biosfer. Diperkirakan $96 \%$ materi organik di biosfer tersusun atas karbon dan unsur esensial lainnya seperti oksigen (O), nitrogen $(\mathrm{N})$ dan hidrogen $(\mathrm{H})$ (Campbell et al., 2005). Karbon bersama unsur-unsur tersebut membentuk berbagai senyawa organik seperti lemak, protein, karbohidrat dan asam nukleat. Senyawa-senyawa organik ini secara terstruktur menyusun tubuh makhluk hidup mulai dari sel, jaringan, organ hingga terbentuk makhluk hidup yang utuh (Ingber, 1998). Atas dasar tersebut, karbon sering disebut juga sebagai the building block of life (Ingber, 1998).

Karbon di alam mengalami suatu siklus materi yang kita kenal dengan istilah siklus karbon. Dalam siklus tersebut, karbon dapat mengalami perpindahan atau pertukaran (exchange) antara reservoir biotik (biosfer) dan abiotik (laut, atmosfer dan kerak bumi). Pertukaran karbon antar reservoir melibatkan beberapa proses di dalamnya, seperti proses kimia, fisika, geologi dan biologi. Proses biologi sendiri melibatkan agen biologi yaitu makhluk hidup. Makhluk hidup utama yang berperan

\footnotetext{
1) Pusat Penelitian Oseanografi LIPI

2) Departemen Perikanan, Fakultas Pertanian, Universitas Gajah Mada
} 
penting dalam siklus karbon adalah kelompok organisme fotosintetik seperti vegetasi di darat dan fitoplankton di perairan (laut).

Fitoplankton merupakan organisme planktonik (melayang-layang di air) yang mampu melakukan fotosintesis sebagaimana tumbuhan di darat. Selama fotosintesis, fitoplankton aktif menyerap karbon dari lingkungannya untuk membentuk senyawa karbohidrat sebagai sumber energi. Meskipun fitoplankton berukuran relatif kecil (mikroskopik), namun jumlah karbon bersih (netto) yang diserap oleh seluruh fitoplankton di laut hampir sama dengan jumlah karbon yang diserap oleh seluruh tumbuhan di darat (Field et al., 1998). Ini artinya, hampir separuh dari jumlah penyerapan karbon dalam kegiatan fotosintesis secara global dilakukan oleh fitoplankton. Pada tulisan ini akan dipaparkan bagaimana peran fitoplankton dalam siklus karbon global. Peran fitoplankton dilihat dari beberapa aspek seperti bagaimana kaitan fitoplankton dengan karbon, seberapa besar kontribusi fitoplankton dalam neraca siklus karbon global dan bagaimana mekanisme sekuestrasi (penyerapan dan penyimpanan) karbon oleh fitoplankton.

\section{KARBON}

Karbon adalah unsur kimia yang memiliki simbol "C". Dalam sistem tabel periodik, karbon masuk dalam golongan IV dan memiliki nomor atom 6 , nomor massa 12 dan massa atom 12,011115 amu (Pierson, 1993). Secara terminologi, "karbon" berasal dari bahasa latin yaitu "carbo" yang artinya "batu bara" (Pierson, 1993). Karbon memang dikenal identik dengan zat berwarna hitam pekat seperti batu bara dan arang. Namun tidak semua senyawa karbon memiliki karakteristik berwarna hitam pekat, misalnya intan yang justru berwarna jernih. Karakteristik ini ditentukan oleh bagaimana struktur kimia senyawa karbon baik dalam bentuk murni atau berikatan dengan unsur lainnya.

Karbon merupakan konstituen dasar semua senyawa organik yang ada di bumi (Pierson, 1993). Hal ini dikarenakan karbon memiliki karakteristik fisika dan kimia unik yang memungkinkan karbon untuk menyokong bentuk kehidupan. Karbon memiliki stabilitas tinggi dan membutuhkan suhu yang tinggi untuk bereaksi. Misalnya untuk bertransisi dari fase padat (solid phase) ke fase gas (gas phase), karbon memerlukan suhu $3642^{\circ} \mathrm{C}$ (Pierson, 1993). Oleh karena, karbon dapat membentuk senyawa polimer stabil itu di suhu bumi yang relatif rendah (Pierson, 1993).

\section{SIKLUS KARBON}

Karbon di alam tidaklah diam, namun mengalami suatu siklus yang menyebabkan karbon mengalami pertukaran (exchange) antar satu reservoir dengan reservoir lainnya. Reservoir merupakan tempat karbon terakumulasi membentuk stok karbon (carbon stock) dan tinggal selama kurun waktu tertentu. Terdapat empat reservoir utama karbon di bumi yaitu atmosfer, hidrosfer (laut), biosfer dan litosfer (Falkowsky et al., 2000). Namun demikian, reservoir atmosfer dan hidrosfer merupakan reservoir utama dalam sistem siklus karbon yang melibatkan fitoplankton. Aliran pertukaran karbon (exchange flux) antar reservoir dapat memakan waktu bulanan bahkan hingga jutaan tahun (Ciais et al., 2013; Rackley, 2017). Diagram pertukaran karbon antar reservoir dapat dilihat pada Gambar 1. 


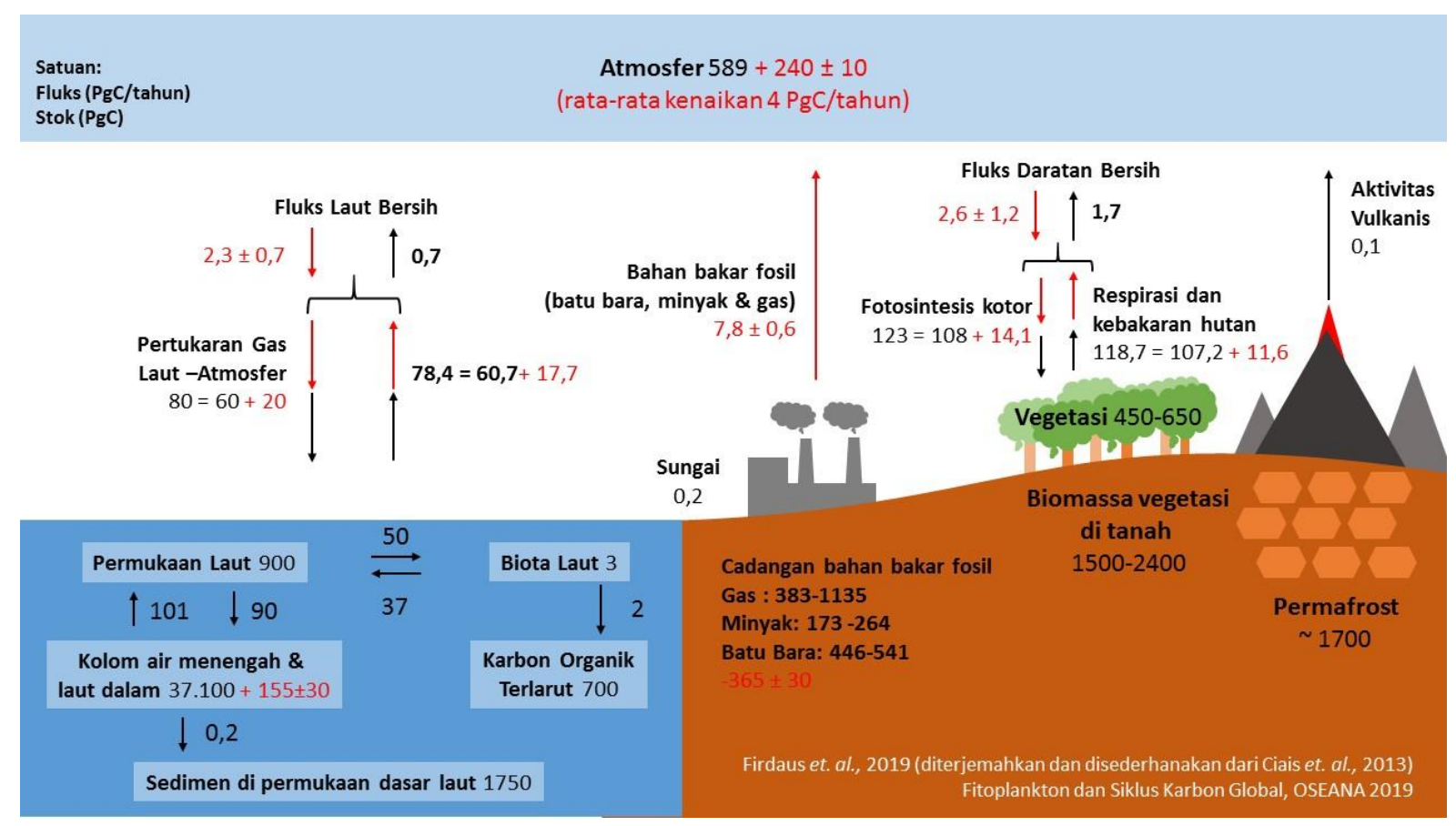

Gambar 1. Siklus Karbon (diterjemahkan dan disederhanakan dari Ciais et al., 2013)

Neraca siklus karbon (carbon budget) secara sederhana dapat dilihat dalam dua bentuk yaitu stok karbon (carbon stock) dan aliran karbon (carbon fluxes). Stok karbon menggambarkan jumlah massa karbon yang tersimpan di dalam reservoir sedangkan aliran karbon menggambar jumlah karbon yang masuk dan keluar reservoir. Pada tulisan ini, stok karbon dinyatakan dengan satuan $\mathrm{PgC}(1 \mathrm{PgC}=$ $10^{15}$ gram C) sementara aliran karbon dinyatakan dengan satuan $\mathrm{PgC} /$ tahun.

\section{Stok Karbon (carbon stock)}

Stok karbon di atmosfer terdapat dalam beberapa bentuk seperti karbon dioksida $\left(\mathrm{CO}_{2}\right)$, karbon monoksida $(\mathrm{CO})$, metana $\left(\mathrm{CH}_{4}\right)$ dan sebagian kecil hidrokarbon (Ciais et al., 2013). Sebagian besar stok karbon di atmosfer terdapat dalam bentuk karbon dioksida yang dapat mencapai $828 \mathrm{Pg}$, sementara dalam bentuk karbon monoksida hanya sebesar 3,7 Pg (Prather et al., 2012; Ciais et al., 2013; Joos et al., 2013). Laju perubahan konsentrasi karbon di atmosfer tidak hanya dipengaruhi oleh aktivitas manusia, tapi juga oleh proses klimatik dan biogeokimia (Falkowski et al., 2000).

Stok karbon di reservoir hidrosfer (laut) diperkirakan 50 kali lebih tinggi dibandingkan di atmosfer, yaitu mencapai 39.000 PgC (Raven et al., 1999; Racley, 2017). Dari jumlah tersebut sebanyak 37.400 Pg terdapat dalam bentuk anorganik dan 1000 Pg dalam bentuk organik (Falkowsky et al., 2000). Karbon terdistribusi dibeberapa kedalaman berbeda. Di permukaan laut sekitar $900 \mathrm{PgC}$, di kolom air laut dalam $37.100 \mathrm{Pg}$ dan di sedimen dasar laut tersimpan kurang lebih 1750 PgC (Ciais et al., 2013). 
Tabel 1. Reservoir karbon (carbon pool) di bumi (Falkowski et al., 2000).

\begin{tabular}{cc}
\hline \multicolumn{1}{c}{ Reservoir } & $\begin{array}{c}\text { Jumlah } \\
(\mathbf{G T})\end{array}$ \\
Atmosfer & 720 \\
Laut & 38.400 \\
- Total Inorganik & 37.400 \\
$\quad$ Surface layer & 670 \\
$\quad$ Deep layer & 36.730 \\
- Organik total & 1.000 \\
Litosfer & \\
- Batuan sedimen & $>60.000 .000$ \\
$\quad$ karbonat & 15.000 .000 \\
- Kerogen & 2.000 \\
Biosfer Terestrial & $600-1.000$ \\
- Biomassa hidup & 1.200 \\
- Biomassa mati & $1-2$ \\
Biosfer Aquatik & 4.130 \\
Bahan Bakar Fosil & 3.510 \\
- Batu-bara & 230 \\
- Minyak & 140 \\
- Gas & 250 \\
- Lain-lain (gambut) & \\
\hline
\end{tabular}

\section{Aliran Karbon (carbon fluxes)}

Menurut Takashi et al. (2009) aliran karbon bersih (net flux) dari atmosfer ke laut sekitar 1,5-2 PgC/tahun, nilai tersebut setara dengan seperempat emisi $\mathrm{CO}_{2}$ antropogenik yang mencapai $7 \mathrm{PgC} /$ tahun. Aliran karbon antara atmosfer dan laut terjadi melalui 3 mekanisme, yaitu pompa kelarutan (solubility pump), pompa karbon biologis (biological carbon pump) dan pompa karbonat (carbonate pump) (Ciais et al., 2003). Pompa biologis dan pompa karbonat bersifat satu arah, yakni aliran karbon dari atmosfer ke laut, sedangkan pompa kelarutan bersifat dua arah tergantung perbedaan gradien konsentrasi $\mathrm{CO}_{2}$ antara laut dan atmosfer. Pompa kelarutan merupakan pertukaran gas karbon (gas exchange) yang terjadi akibat perbedaan konsentrasi $\mathrm{CO}_{2}$ antara laut dan atmosfer. Proses tersebut terjadi secara difusi dan berlangsung di bagian permukaan laut.

\section{FITOPLANKTON}

Fitoplankton adalah kelompok plankton yang mampu melakukan fotosintesis (Nybakken et al., 2005) (Gambar 2). Plankton adalah kelompok makhluk hidup yang melayang-layang di dalam air dan memiliki kemampuan berenang terbatas sehingga tidak mampu melawan gerakan air (Nybakken et al., 2005). Plankton memiliki ukuran bervariasi mulai dari ukuran $0,02 \mu \mathrm{m}$ (femtoplankton) hingga $20 \mathrm{~cm}$ lebih (megaplankton) (Nybakken et al., 2005). Meski berukuran relatif kecil, fitoplankton memiliki peran ekologis yang besar di dalam biosfer. Fitoplankton merupakan fondasi utama piramida makanan di dalam ekosistem perairan dan menempati lebih dari 70 persen luas permukaan bumi. 


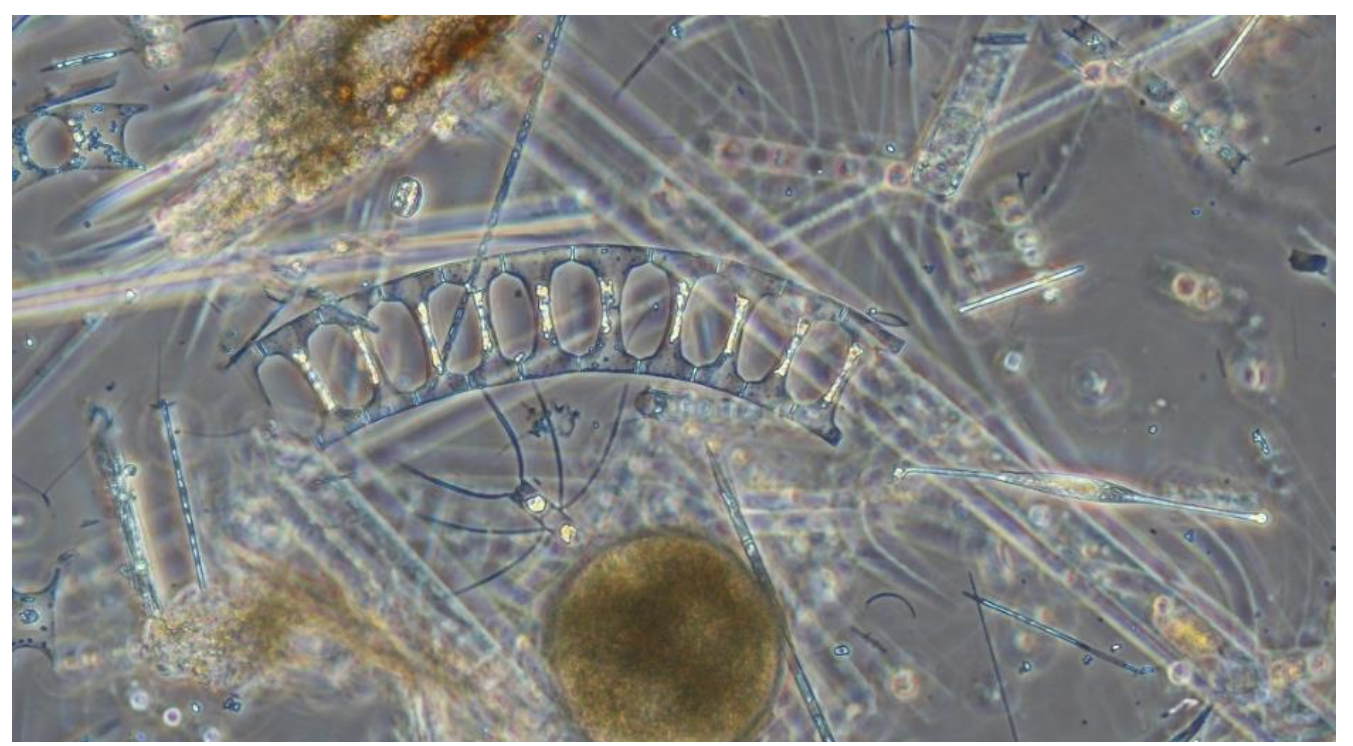

Gambar 2. Berbagai jenis fitoplankton dilihat dibawah mikroskop dengan perbesaran 10 kali dan filter phase contrast (sumber: dokumentasi Arief Rachman).

\section{FITOPLANKTON DAN SIKLUS KARBON}

Fitoplankton memiliki keterkaitan yang erat dengan unsur karbon dan juga siklus karbon. Karbon dibutuhkan fitoplankton untuk membentuk senyawa karbohidrat $\left(\mathrm{C}_{6} \mathrm{H}_{12} \mathrm{O}_{6}\right)$ yang merupakan sumber energi bagi fitoplankton. Senyawa karbohidrat tersebut disintesis oleh fitoplankton melalui suatu reaksi anabolik yang dikenal dengan fotosintesis. Fotosintesis inilah yang menjadi kunci utama peran fitoplankton dalam siklus karbon.

Selama fotosintesis, fitoplankton aktif menyerap karbondioksida dari kolom air. Karbondioksida tersebut diubah menjadi senyawa karbohidrat $\left(\mathrm{C}_{6} \mathrm{H}_{12} \mathrm{O}_{6}\right)$ melalui suatu reaksi kimia siklik yang dikenal dengan nama Siklus Calvin (Falkowski \& Raven, 2007). Untuk menghasilkan satu molekul karbohidrat $\left(\mathrm{C}_{6} \mathrm{H}_{12} \mathrm{O}_{6}\right)$ dibutuhkan enam molekul karbon dioksida $\left(6 \mathrm{CO}_{2}\right)$ dan enam molekul air $\left(6 \mathrm{H}_{2} \mathrm{O}\right)$. Air dibutuhkan sebagai sumber energi dalam siklus Calvin dan diperoleh melalui oksidasi molekul air dengan bantuan energi cahaya matahari. Oksidasi molekul air tersebut menghasilkan energi berupa ATP dan NADPH. Selain energi, oksidasi molekul air juga menghasilkan produk samping berupa oksigen $\left(\mathrm{O}_{2}\right)$. Oksigen yang dihasilkan oleh kegiatan fotosintesis fitoplankton di laut diketahui hampir sama banyaknya dengan oksigen yang dihasilkan seluruh vegetasi di darat. Secara sederhana fotosintesis dapat digambarkan dalam bentuk persamaan kimia berikut (Falkowski \& Raven, 2007):

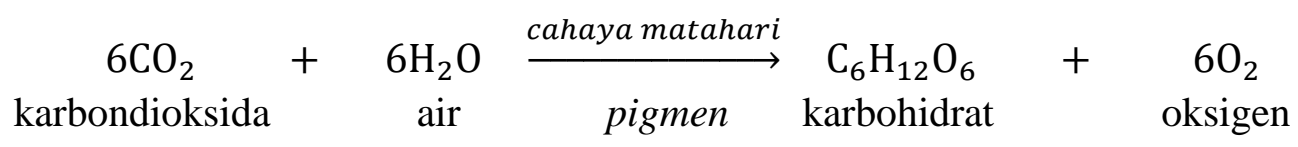


Penyerapan unsur karbon oleh fitoplankton selama fotosintesis menyebabkan adanya perpindahan karbon dari dalam air (hidrosfer) ke dalam tubuh fitoplankton. Karbon tersebut disimpan dalam tubuh fitoplankton dalam bentuk biomassa fitoplankton itu sendiri. Pada skala individu jumlah karbon yang diserap oleh fitoplankton dari dalam air sangat kecil, tetapi jika diakumulasi dalam skala global jumlahnya sangatlah besar, mencapai 40-50 Pg karbon bersih setiap tahunnya (Field et al., 1988).

\section{PRODUKTIVITAS PRIMER FITOPLANKTON}

Laju pembentukan senyawa organik oleh organisme autotrof seperti fitoplankton selama waktu tertentu disebut dengan produktivitas primer. Meskipun demikian, satuan produktivitas primer tidak dinyatakan dengan jumlah senyawa organik yang dihasilkan. Produktivitas primer dinyatakan dengan jumlah total karbon yang diserap untuk membentuk senyawa organik tersebut. Oleh karena itu satuan produktivitas primer dinyatakan dengan satuan molekul karbon "C". Secara umum, produktivitas primer dapat dilihat dari dua bentuk, yaitu produktivitas primer kotor (gross primary productivity) dan produksi primer bersih (net primary productivity). Produktivitas primer kotor (GPP) menggambarkan jumlah total karbon yang digunakan untuk membentuk senyawa organik (karbohidrat), sedangkan produktivitas primer bersih (NPP) adalah jumlah karbon yang digunakan (GPP) kemudian dikurangi dengan kebutuhan respirasi organisme itu sendiri untuk mempertahankan hidup. Nilai NPP ini yang kemudian dimanfaatkan oleh makhluk hidup lain (organisme heterotrof) sebagai sumber makanan.

$$
\mathrm{NPP}=\mathrm{GPP}-\text { respirasi }
$$

Berbagai penelitian telah dilakukan untuk menghitung total produktivitas primer secara global (Nielsen et al., 1952; Nielsen et al., 1957, Longhurst et al., 1995; Field et al., 1998). Melalui metode remote sensing, diperkirakan produktivitas primer bersih secara global mencapai 104,9 PgC/tahun (Field et al., 1998). Daratan diperkirakan berkontribusi sebesar 56,4 $\mathrm{PgC}(53,8 \%)$ sedangkan laut 48,5 $\mathrm{PgC} \quad(45,2 \%)$. Berdasarkan nilai tersebut dapat dilihat bahwa laut berkontribusi hampir separuh dari produktivitas primer bersih global. Produksi primer bersih di laut sebagian besar dilakukan oleh fitoplankton, yaitu mencapai 45-50 PgC/tahun, sementara padang lamun (seagrass) hanya sebesar 0,3 PgC/tahun (Longhrust et al., 1995; Field et al., 1998; Fourqurean et al., 2012). Nilai tersebut menunjukkan bahwa fitoplankton di laut berperan besar dalam siklus karbon global (Sigman et al., 2003).

Beberapa kelompok besar fitoplankton menunjukan kontribusi berbeda terhadap total produksi primer global. Misalnya kelompok diatom yang dikenal memiliki bentuk indah karena memiliki dinding sel seperti ornamen yang terbuat dari silika (frustule) (Gambar 3). Kontribusi diatom dalam siklus karbon diperkirakan mencapai $38-53 \%$ dari total produktivitas primer global, atau sekitar 19,1 PgC/tahun (Yool et al., 2003 \& Thorthon, 2012). Melalui pendekatan remote sensing, konstribusi diatom (microphytoplankton) di daerah upwelling dapat mencapai $70 \%$ dari produktivitas primer perairan. Di daerah temperate dan subpolar kontribusinya dapat mencapai 50\% saat musim semi-panas (Uitz et al., 2010). 


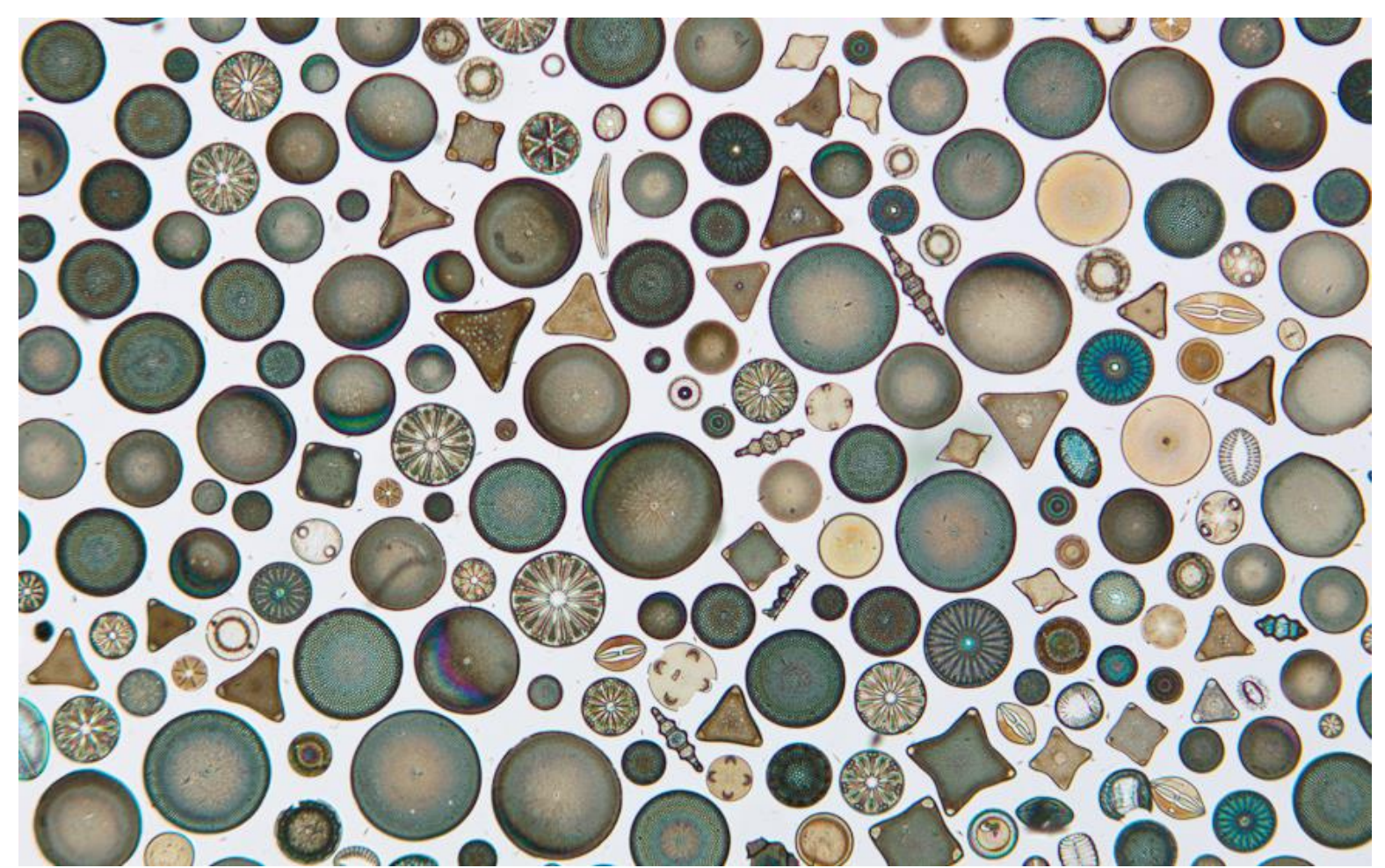

Gambar 3. Berbagai jenis diatom (Flickr: California Academy of Sciences)

Sianobakteria (bakteri hijau-biru) merupakan kelompok fitoplankton dari golongan prokariotik karena tidak memiliki membran inti sel sebagaimana bakteri pada umumnya. Kelompok ini sering disebut juga dengan alga atau ganggang hijau-biru (blue green algae) (Gambar 4). Sianobakteria diperkirakan berkontribusi terhadap sekitar $25 \%$ produktivitas primer bersih laut (Flombaum et al., 2013). Secara parsial, kelompok sianobakteria Prochlorococcus diperkirakan berkontribusi sekitar 9\% dari produktivitas primer kotor di wilayah eastern equatorial Pacific, $39 \%$ di wilayah eastern equatorial Pacific dan mencapai 82 $\%$ di daerah subtropical north Pacific (Liu et al., 1997).
Jika dikelompokkan berdasarkan ukurannya diketahui terdapat tiga kelompok fitoplankton dengan kontribusi berbeda terhadap neraca siklus karbon, yaitu kelompok mikrofitoplankton, nanofitoplankton dan pycofitoplankton. Kelompok mikrofitoplankton berukuran $>20 \mu$ diketahui berkontribusi sebesar 15 PgC/tahun (32\%). Kelompok nanoplankton dengan ukuran $2-20 \mu$ diketahui berkontribusi sebesar $20 \mathrm{PgC} /$ tahun (44\%), sedangkan kelompok pikoplankton dengan ukuran $<2 \mu$ berkontribusi sebesar 11 PgC/tahun (24\%) (Uitz et al., 2010). Kelompok mikroplankton didominasi oleh kelompok diatom dan dinoflagellata, sedangkan pikoplankton didominasi oleh kelompok sianobakteria (Uitz et al., 2010). 


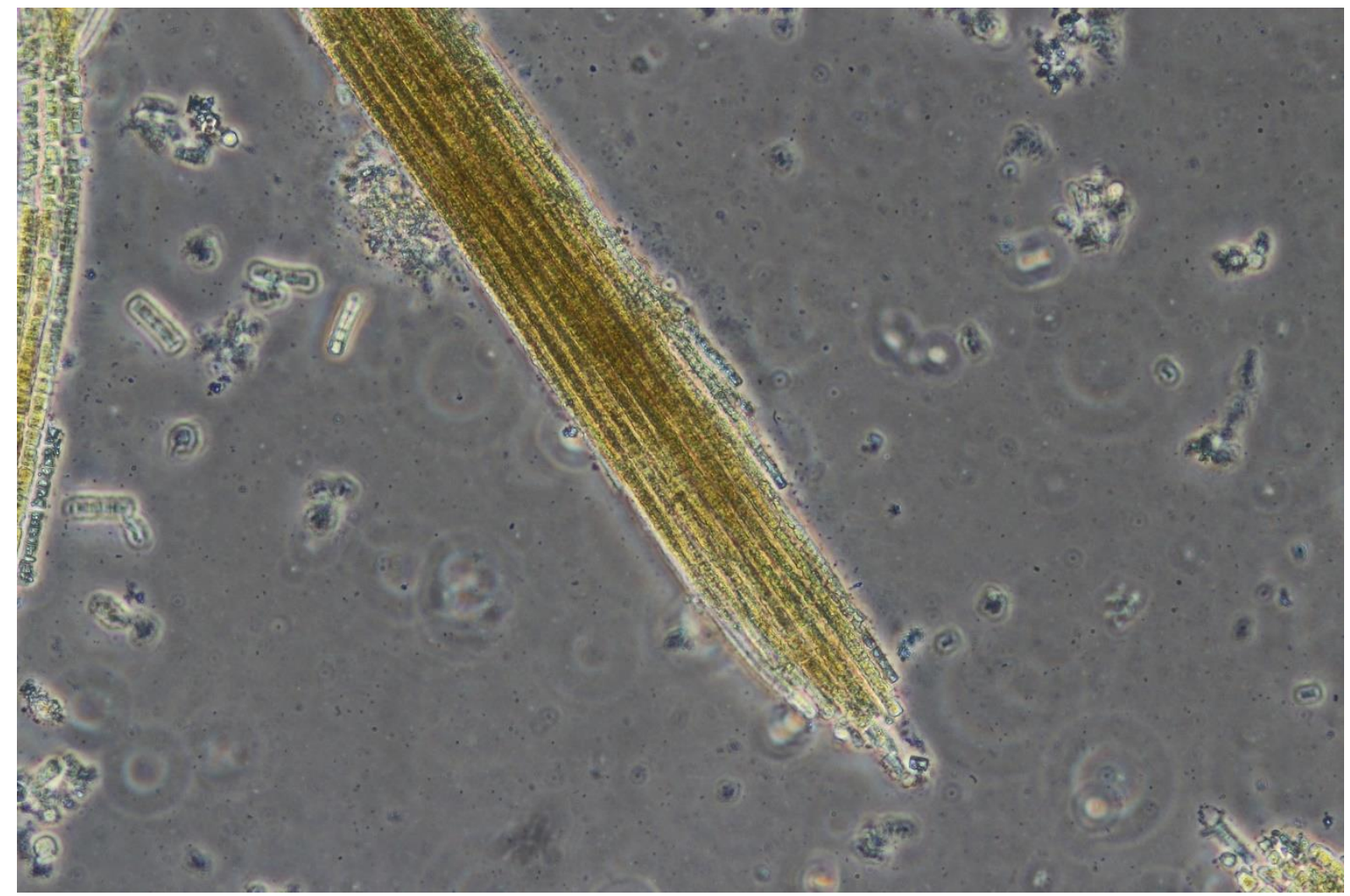

Gambar 4. Salah satu jenis sianobakteria, Trichodesmium eurythraenum (dokumentasi Arief Rachman).

\section{SEKUESTRASI KARBON OLEH FITOPLANKTON}

Sekuestrasi karbon adalah proses penyerapan karbon dari atmosfer dan kemudian menyimpannya dalam waktu yang lama (Lal, 2008). Sekuestrasi karbon di laut terjadi dalam skala besar dan melibatkan berbagai kelompok organisme seperti terumbu karang, moluska, lamun, hutan bakau dan plankton. Sekuestrasi karbon di laut sebagian besar dilakukan oleh fitoplankton melalui suatu mekanisme yang dikenal dengan istilah pompa karbon biologis (biological carbon pump) dan pompa karbonat (carbonate pump).

\section{Pompa karbon biologis (Biological Carbon Pump)}

Biological Carbon Pump adalah aliran partikulat karbon organik (particulate organic carbon) dari permukaan ke dasar laut (Volk et al., 1985). Biological Carbon Pump (BCM) merupakan mekanisme penyerapan dan penyimpanan karbon (carbon sequestration) di dasar laut yang terjadi melalui proses biologis (Hain et al., 2014). Setiap tahun biological Carbon Pump diperkirakan mentranspor 4-6 Pg karbon ke dasar laut, atau sekitar 10 persen dari nilai NPP laut (Field et al., 1998; Hain et al., 2014).

Mekanisme biological carbon pump diawali dengan aktivitas fotosintesis fitoplankton di zona fotik. Aktivitas tersebut menghasilkan bahan organik dalam bentuk biomassa fitoplankton. Biomassa fitoplankton tidak seluruhnya dimakan oleh organisme laut (primary consument) akan tetapi sebagian terdekomposisi atau tenggelam ke dasar laut. Fitoplankton yang tenggelam membentuk agegrat dengan biomassa fitoplankton lainnya sehingga 
berukuran lebih besar. Agegrat-agegrat biomassa fitoplankton yang berjatuhan tersebut menciptakan semacam "hujan" bahan organik di kolom air yang dikenal dengan istilah marine snow (Sigman et al., 2012). Fenomena marine snow inilah yang menjadi mekanisme transpor karbon (carbon flux) dari permukaan ke dasar laut.

\section{Pompa karbonat (Carbonate Pump)}

Pompa karbonat merupakan mekanisme transpor karbon dari permukaan ke dasar laut dalam bentuk kalsium karbonat $\left(\mathrm{CaCO}_{3}\right)$. Pompa karbonat masih merupakan bagian dari sistem pompa karbon biologis (biological carbon pump) dan terjadi dalam skala waktu 100-1000 tahun (Salter et al., 2014). Fitoplankton yang berperan dalam pompa karbonat adalah fitoplankton dari kelompok kokolitofor (coccolithophore).

Kelompok kokolitofor mampu memanfaatkan karbon untuk membentuk cangkang keras (eksoskeleton) dengan cara memproduksi senyawa biomineral berupa kalsium karbonat $\left(\mathrm{CaCO}_{3}\right)$. Cangkang tersebut berupa plat kalsium karbonat (calcite) yang menutupi seluruh permukaan sel dan disebut dengan coccolith (Monteiro et al., 2016; Shutler et al., 2013). Cocolith diproduksi dengan memanfaatkan senyawa kalsium $\left(\mathrm{Ca}^{+}\right)$dan karbonat $\left(\mathrm{CO}_{3}^{-}\right)$yang terlarut di dalam air melalui suatu proses biologis yang dikenal dengan istilah biological calcification atau biokalsifikasi.

Iglesias-Rodriguez et. al. (2018) meneliti pengaruh kadar $\mathrm{CO}_{2}$ terhadap proses biokalsifikasi kokolitofor. Dia dan tim nya melakukan aerasi gas karbondioksida terhadap kultur salah satu jenis kokolitofor, Emiliania huxleyi. Hasil penelitianya menunjukan bahwa peningkatan kadar $\mathrm{CO}_{2}$ berpengaruh terhadap meningkatnya aktivitas biokalisifikasi sehingga jumlah plat kalsium karbonat yang dibentuk lebih banyak. Biokalsifikasi sebenarnya tidak hanya dilakukan oleh kokolitofor, akan tetapi oleh berbagai jenis organisme laut lainnya seperti terumbu karang, spons, moluska, foraminifera, echinodermata dan lain-lain. Namun demikian, kokolitofor merupakan organisme yang paling aktif melakukan biokalsifikasi. Aktivitas biokalsifikasi kokolitofor dapat memengaruhi tekanan parsial karbondioksida $\left(p \mathrm{CO}_{2}\right)$ air laut sehingga berpengaruh pada difusi karbondioksida ke permukaan laut (Shutter et al., 2013).

Cangkang kokolitofor terbuat dari kalsium karbonat sehingga bersifat keras dan tidak mudah hancur. Sifat tersebut menyebabkan cangkang kokolitofor mampu bertahan hingga mencapai dasar laut. Tidak seperti jenis fitoplankton lain yang habis terdekomposisi sebelum sampai di dasar laut. Cangkang-cangkang kokolitofor yang tenggelam ke dasar laut membentuk "hujan" kalsium karbonat di kolom air (Monteiro et al., 2016). Hujan kalsium karbonat inilah yang menjadi mekanisme transpor karbon dalam fenomena pompa karbonat. Di dasar laut, cangkang-cangkang kokolitofor terdeposisi selama ribuan tahun membentuk carbon geological sink berupa sedimen kokolitofor (coccolithopore ooze) dalam jumlah besar (Monteiro et al., 2016). Beberapa jenis kokolitofor dapat dilihat pada gambar 5. 


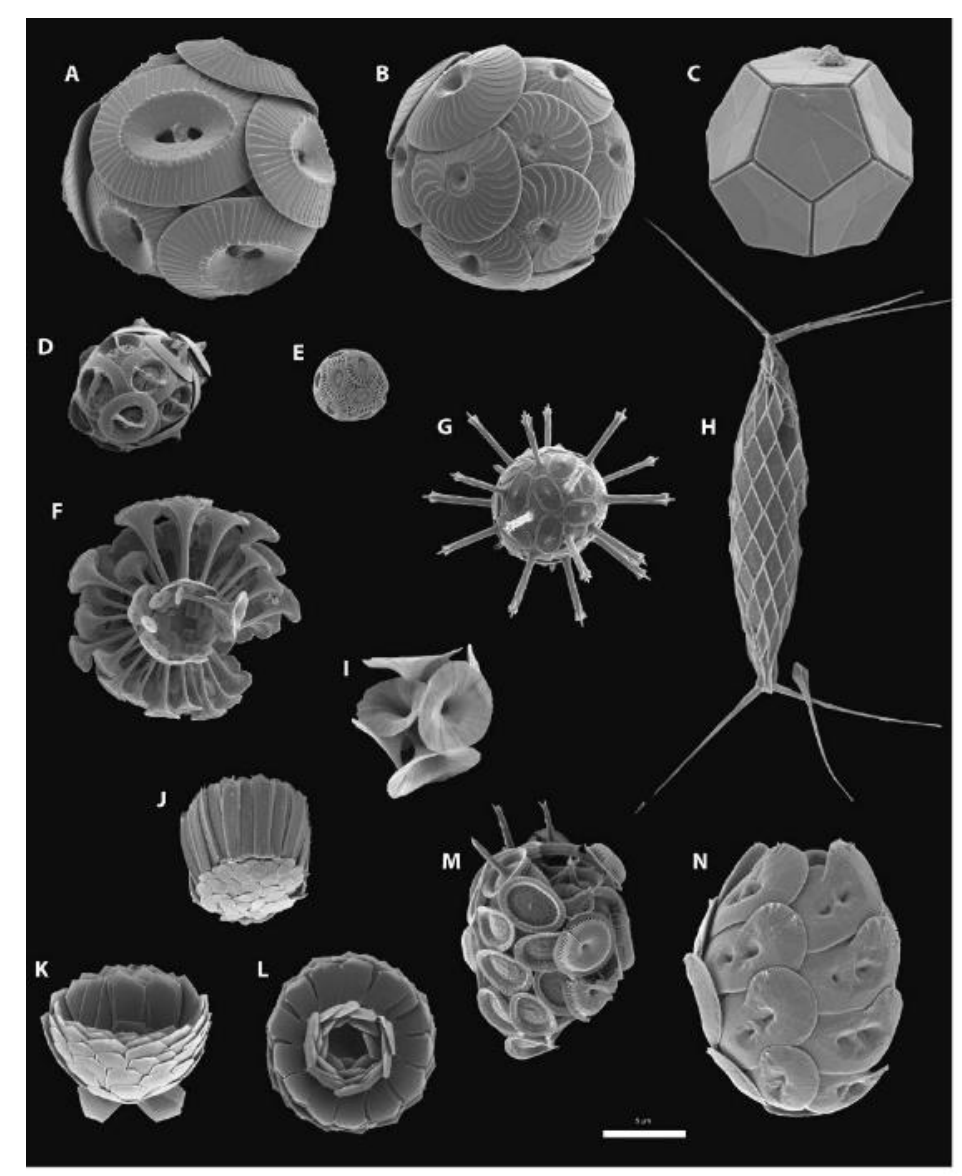

Gambar 5. Berbagai jenis kokolitofor: (A) Coccolithus pelagicus, (B) Calcidiscus leptoporus, (C) Braarudosphaera bigelowii, (D) Gephyrocapsa oceanica, (E) E. huxleyi, (F) Discosphaera tubifera, (G) Rhabdosphaera clavigera, (H) Calciosolenia murrayi, (I) Umbellosphaera irregularis, (J) Gladiolithus flabellatus, (K \& L) Florisphaera profunda, (M) Syracosphaera pulchra dan (N) Helicosphaera carteri (Monteiro et al, 2016).

Sedimen kokolitofor di dasar laut dapat mengalami pengerasan dan membentuk batuan sedimen yang kita kenal dengan nama batu kapur atau batu gamping (limestone). Di beberapa tempat, batuan sedimen kokolitofor tersebut terangkat ke permukaan laut akibat aktivitas tektonik. Sebagai contoh, di negara Inggris ditemukan singkapan sedimen kokolitofor yang dikenal dengan nama White Cliffs of Dover (Gambar 6). Singkapan sedimen kokolitofor tersebut berupa tebing batu kapur berwarna putih dengan tinggi $106 \mathrm{~m}$ dan panjang mencapai $13 \mathrm{~km}$. White Cliffs of Dover terbentuk ratusan juta tahun lalu dan terangkat ke permukaan laut akibat pergerakan lempeng bumi. White Cliffs of Dover merupakan salah satu contoh bentuk sekuestrasi karbon (carbon sequestration) secara alami di alam (Witty, 2011). Mekanisme ini berperan penting dalam menurunkan kadar $\mathrm{CO}_{2}$ di atmosfer. 


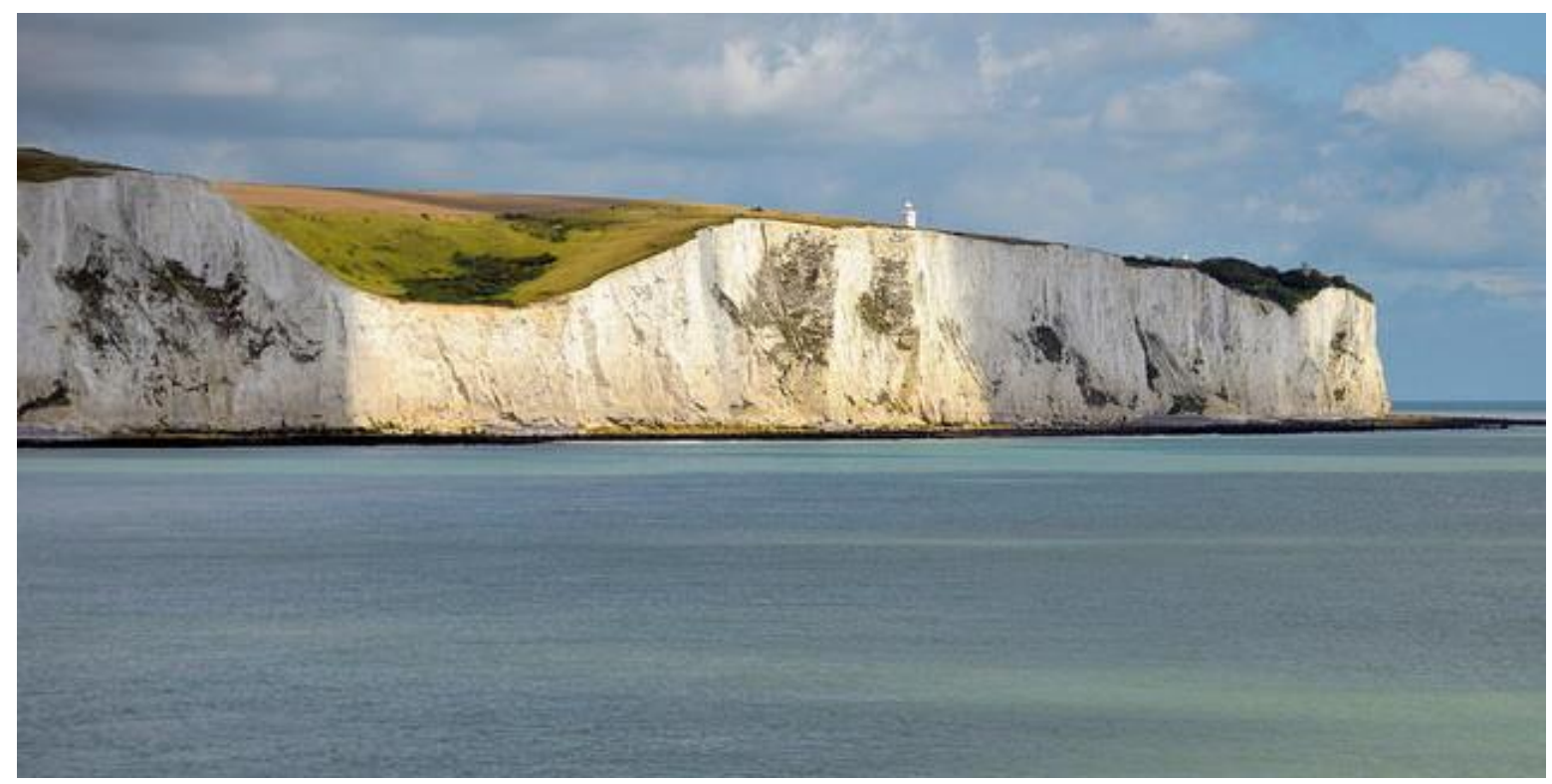

Gambar 6. White Cliffs of Dover di Inggris (Sumber: Flickr/jpellgen).

Kokolitofor memiliki kontribusi besar dalam siklus karbon global (Krumhardt et al., 2017, Monteiro et al., 2016; Poulton et al., 2007). Diperkirakan jumlah karbon yang diserap oleh kokolitofor dari aktivitas fotosintesis dan pembentukan cangkang (kalsifikasi) dapat mencapai satu hingga sepuluh persen dari produktivitas primer di laut, bahkan saat terjadi ledakan populasi dapat mencapai $40 \%$ (Poulton et al., 2007). Dengan persentase tersebut, kokolitofor menjadi salah satu organisme yang paling produktif melakukan biokalsifikasi di planet bumi (Monteiro et al., 2016). Hal ini juga didukung oleh fakta bahwa kokolitofor merupakan organisme pengkalsifikasi yang paling melimpah (most abundant) di laut (Kumhardt et al., 2017).

\section{PENUTUP}

Berbagai penelitian menunjukan bahwa fitoplankton memainkan peran penting (critical role) dalam siklus karbon global. Fitoplankton bertanggung jawab dalam aliran karbon (carbon flux) dari reservoir atmosfer ke reservoir hidrosfer (laut). Aliran karbon tersebut terjadi melalui proses fotosintesis di daerah fotik. Dalam neraca siklus karbon global, setiap tahun fitoplankton menyerap sekitar 40-60 Pg karbon bersih dari atmosfer ke laut. Dari jumlah tersebut, sekitar 4-6 Pg karbon disekuestrasi di dasar laut. Sekuestrasi karbon oleh fitoplankton terjadi melalui mekanisme vertical flux partikulat karbon organik (particulate organic carbon) dan carbonate pump yang merupakan bagian dari sistem biological carbon pump di laut. Penelitian dengan fokus mengkaji kaitan biological carbon pump dan komunitas fitoplankton ke depan perlu ditingkatkan, karena penelitian tersebut masih terbatas. Kajian tersebut penting untuk membantu kita mengetahui bagaimana fitoplankton mensekuestrasi karbon di masa depan. Khususnya dibawah isu pengaruh perubahan iklim yang diprediksi akan mempengaruhi ketersediaan karbon dan nutrien, serta perubahan stratifikasi parameter suhu dan cahaya di perairan. 


\section{DAFTAR PUSTAKA}

Campbell, N. A. and J. B. Reece. 2005.

Biology. Pearson-Benjamin

Cummings, San Fransisco: 1231pp.

Ciais, P., S. Chris, B. Govindasamy, L. Bopp, V. Brovkin, J. Canadell, A. Chhabra, R. Defries, J. Galloway, M. Heimann, C. Jones, C. Le Quere, R.B. Myneni, S. Piao, P. Thornton. 2013. Carbon and other biogeochemical cycles. Climate Change 2013: The Physical Science Basis: 465-570.

Croswell, K. 1996. The Alchemy of the Heavens. Oxford University Press, Oxford: 340pp.

Falkowski, P. G., R. J. Scholes, E. Boyle, J. Canadell, D. Canfield, J. Elser, N. Gruber, K. Hibbard, P. Högberg, S. Linder, F. T. Mackenzie, B. Moore III, T. Pedersen, Y. Rosenthal, S. Seitzinger, V. Smetacek and W. Steffen. 2000. The Global Carbon Cycle : A Test of Our Knowledge of Earth as a System. Science, New Series, Vol. 290 (5490): 291-296.

Falkowski, P. G. and J. A. Raven. 2007. Aquatic Photosynthesis: (Second Edition). Princeton University Press. USA: $488 \mathrm{pp}$.

Field, C. B., M. J. Behrenfeld, J. T. Randerson and P. G. Falkowski. 1998. Primary production of the biosphere: Integrating terrestrial and oceanic components. Science 281: 237-240.

Flombaum, P., J. L. Gallegos, R. A. Gordillo, J. Rincón, L. L. Zabala, N. Jiao, D. M. Karl, W. K. W. Li, M. W. Lomas, D. Veneziano, C. S. Vera, J. A. Vrugt, and A. C. Martiny. 2013. Present and future global distributions of the marine
Cyanobacteria Prochlorococcus and Synechococcus. Proceedings of the National Academy of Sciences 110 (24). Pp 9824-9829.

Fourqurean, J. W., C. M. Duarte, H. Kennedy, N. Marbà, M. Holmer, M. A. Mateo, E. T. Apostolaki, G. A. Kendrick, D. Krause-Jensen, K. J. McGlathery and O. Serrano. 2012. Seagrass ecosystems as a significant global carbon stock. Nature Geoscience 5: 505-509.

Hain, M. P., D. M. Sigman, and G. H. Haug. 2014. The biological Pump in the Past. Treatise on Geochemistry, Edition: 2, Chapter: 8.18, Publisher: Elsevier: 485-51.

Iglesias-Rodriguez, M. D., P. R. Halloran, R. E. M. Rickaby, I. R. Hall, E. Colmenero-Hidal. 2008. Phytoplankton Calcification in a High- $\mathrm{CO}_{2}$ World. Science.Vol 320 (5874): 336-340

Ingber, D. E. 1998. The Architecture of Life. Scientific American: 48-57.

Joos, F., R. Roth, J. S. Fuglestvedt, G. P. Peters, I. G. Enting, W. von Bloh, V. Brovkin, E. J. Burke, M. Eby, N. R. Edwards, T. Friedrich, T. L. Frölicher, P. R. Halloran, P. B. Holden, C. Jones, T. Kleinen, F. T. Mackenzie, K. Matsumoto, M. Meinshausen, G. K. Plattner, A. Reisinger, J. Segschneider, G. Shaffer, M. Steinacher, K. Strassmann, K. Tanaka, A. Timmermann, and A. J. Weaver. 2013. Carbon dioxide and climate impulse response functions for the computation of greenhouse gas metrics: A multi-model analysis. Atmospheric Chemistry and Physics 13: 2793-2825. 
Krumhardt, K. M., N. S. Lovenduski, M. D. Iglesias-Rodriguez and J. A. Kleypas. 2017. Coccolithophore growth and calcification in a changing ocean. Progress in Oceanography 159: 276-295.

Lal, Rattan. 2008. Carbon sequestration. Philosophical Transactions of the Royal Society B: Biological Sciences 363 (1492): 815-830.

Liu, H., H. A. Nolla and L Campbell. 1997. Primary production of prochlorophytes, cyanobacteria, and eucaryotic ultraphytoplankton: Measurements from flow cytometric sorting. Aquatic Microbial Ecology. Vol 12: Pp 39-47.

Longhurst, A., S. Sathyendranath, T. Platt and C. Caverhill. 1995. An estimate of global primary production in the ocean from satellite radiometer data. Journal of Plankton Research 17 (6): 1245-1271.

Monteiro, F.M., L. T. Bach, C. Brownlee, P. Bown, R. E. M. Rickaby, A. J. Poulton, T. Tyrrell, L. Beaufort, S. Dutkiewicz, S. Gibbs, M. A. Gutowska, R. Lee, U. Riebesell, J. Young and A. Ridgwell. 2016. Why marine phytoplankton calcify. Science Advances 2 (7): 1-14.

Nielsen. E. S. 1952. The use of radioactive carbon (C14) for measuring organic production in the sea. J. Cons. $\mathrm{InL}$ Explor. Mer. 18: 117-140.

Nielsen. E. S and E.A. Jensen. 1957. The autotrophic production of organic matter in the oceans. Galathea Rep. 1: 49-124.

Nybakken, J.W and M.D. Bertness. 2005. Marine Biology, An Ecological Approach. Pearson Education. San Francisco: 579pp.
Pierson, H.O. 1993. Handbook of Carbon, Graphite, Diamond and Fullerenes Properties, Processing and Applications. William Andrew Publishing, Noyes. USA: 419pp.

Poulton, A.J., T. R. Adey, W. M. Balch and P. M. Holligan. 2007. Relating coccolithophore calcification rates to phytoplankton community dynamics: Regional differences and implications for carbon export. Deep Sea Research Part II: Topical Studies in Oceanography 54 (5-7): 538-557.

Prather, M. J., C. D. Holmes and J. Hsu. 2012. Reactive greenhouse gas scenarios: Systematic exploration of uncertainties and the role of atmospheric chemistry. Geophys. Res. Lett. 39 (9): ppL9803.

Rackley, S. A. 2017. Carbon Capture and Storage. Butterworth-Heinemann. Elsevier. Oxford: 408pp.

Raven, J. A., and P. G. Falkowski. 1999. Oceanic sinks for atmospheric $\mathrm{CO}_{2}$. Plant, Cell and Environment 22 (6): 741-755.

Salter, I., R. Schiebel, P. Ziveri, A. Movellan, R Lampitt and G. A. Wolff. 2014. Carbonate counter pump stimulated by natural iron fertilization in the Polar Frontal Zone. Nature Geoscience 7 (12): 885-889.

Shutler, J. D., P. E. Land, C. W. Brown, H. S. Findlay, C. J. Donlon, M. Medland, R. Snooke, and J. C. Blackford. 2013. Coccolithophore surface distributions in the North Atlantic and their modulation of the air-sea flux of $\mathrm{CO} 2$ from 10 years of satellite Earth observation data. Biogeosciences 10: 2699-2709. 
Sigman, D. M., and G. H. Haug. 2003. The Biological Pump in the Past. Treatise on Geochemistry: 491-528.

Sigman, D. M. and M. P. Hain. 2012. The Biological Productivity of the Ocean. Nature Education: 1-16.

Takahashi, T., S. C. Sutherland, R. Wanninkhof, C. Sweeney, R. A. Feely, D. W. Chipman, B. Hales, G. Friederich, F. Chavez, C. Sabine, A. Watson, D. C. E. Bakker, U. Schuster, N. Metzl, H. YoshikawaInoue, M. Ishii, T. Midorikawa, Y. Nojiri, A. Körtzinger, T. Steinhoff, M. Hoppema, J. Olafsson, T. S. Arnarson, B. Tilbrook, T. Johannessen, A. Olsen, R. Bellerby, C. S. Wong, B. Delille, N.R. Bates and H. J. W. de Baar. 2009. Climatological mean and decadal change in surface ocean $\mathrm{pCO} 2$, and net sea-air CO2 flux over the global oceans. Deep Sea Research Part II: Topical Studies in Oceanography 56 (8-10) 554-577.

Thornton, D.C.O. 2012. Primary Production in the Ocean. Advances in Photosynthesis - Fundamental Aspects. 563-588

Uitz, J. H. Claustre, B. Gentili and D. Stramski. 2010. Phytoplankton class-specific primary production in the world's oceans: Seasonal and interannual variability from satellite observations. Global Biochemical Cycles. American Geophysical Union. Vol. 24 (3).

Volk, T and M. I. Hoffert. 1985, Ocean carbon pumps: analysis of relative strengths and efficiencies in oceandriven atmospheric $\mathrm{CO} 2$ changes. in ET Sundquist \& WS Broecker (eds), The carbon cycle and atmospheric $\mathrm{CO}_{2}$ : natural variations Archean to present. Chapman conference papers, 1984. American Geophysical Union; Geophysical Monograph 32: 99-110.

Witty, M. 2011. The white Cliffs of Dover are an Example of Natural Carbon Sequestration. Ecologia 1 (1): 23-30.

Yool, A., T. Tyrrell. 2003. Role of Diatoms in Regulating the Ocean's Silicon Cycle. Global Biogeochemical Cycles, Vol. 17, No. 4, Pp 1-21. 